\title{
SUSTAINABLE CONSUMPTION - BETWEEN THEORY AND PRACTICE
}

Wladysława LUCZKA, Department of Economics, Faculty of Economic and Life Sciences, Poznan University of Life Sciences, ul. Wojska Polskiego 28, 60-637 Poznan, Poland; luczka@up.poznan.pl

Joanna SMOLUK-SIKORSKA, Department of Economics, Faculty of Economic and Life Sciences, Poznan University of Life Sciences, ul. Wojska Polskiego 28, 60-637 Poznan, Poland; smoluk@ up.poznan.pl (corresponding author)

The aim of the considerations is to define the essence of sustainable consumption as one of the conditions of the practical realisation of sustainable development concept. The paper underlines the importance of sustainable consumption implementation as well as its importance for the future development. The existence of narrow and broad understanding of sustainable consumption was indicated in the elaboration. In the first case, it concerns environmental aspects, whereas in the second, it covers three dimensions: economic, environmental and social ones. The authors also indicated the practices in fames of sustainable consumption on different levels, i.e. individuals, households and governmental ones. They considered different aspects of sustainable consumption, which is an alternative occurrence in relation to consumptionism and manifests itself in eco-consumption, collaborative consumption, deconsumption and responsible consumption. Nevertheless, sustainable consumption is on the margin of mainstream consumption processes. The elaboration also presents a number of factors and obstacles for realisation of the sustainable consumption, both on demand and supply side. First, it requires fundamental changes in value system, social awareness and consumer habits. The state should use particular tools (informational, legal, economic and financial ones) to enable realisation of the sustainable consumption concept.

Keywords: change, consumption pattern, development, sustainability

\section{INTRODUCTION}

Population all over the world is currently facing a number of challenges related to the environment, sustainability and social inequity. One of the main elements of the sustainable development, which contributes to meeting the challenges, is sustainable consumption. It is a relatively recent term, however it is defined in many different ways covering diverse aspects occurring on governmental, business households and individual levels. Consumption is strictly connected to purchase and each purchase has implications of ethical, resource, waste and community impact implications (Moisander, 2007).

The aim of the paper is to attempt to define the essence of sustainable consumption as one of the conditions of the practical realisation of the sustainable development concept. The main research task put by the authors were:

1) determining the meaning of sustainable consumption for realisation of the sustainable development concept,

2) reviewing the literature on sustainable consumption and discussion on its concept, classifications, aspects, dimensions, aims and manifestations,

3) recognition of factors and obstacles for sustainable consumption concept practical realisation, particularly in governmental policy strategy sphere.

In order to achieve this goal and realise the above-mentioned tasks, the review of the literature concerning sustainable development and sustainable consumption was conducted. Basing on that review, the methods of rational economic reasoning were applied, including induction, deduction method, comparative analysis as well as the analysis and critics of literature.

\section{SUSTAINABLE CONSUMPTION AS AN AIM AND CONDITION OF SUSTAINABLE DEVELOPMENT}

Both concept of sustainable development and originating from it - concept of sustainable consumption are characterised by great variety and interpretational range. The sustainable development was first defined by The World Commission on Environment and Development (so-called Bruntland Commission), in the report "Our Common Future" (1987) prepared for the UNO. It was assumed in the paper, that it is a development that ensures meeting of needs of present generations without compromising the ability of future generations to meet their own needs. Quite general definition of the sustainable development caused formulation of a number of different interpretations and approaches. According to Redclift from the King College "Since path-breaking deliberations of Bruntland Commission, the

Copyright (C) 2017 The Authors. Published by Aleksandras Stulginskis University. This is an open-access article distributed under the terms of the Creative Commons Attribution License (CC-BY 4.0), which permits unrestricted use, distribution, and reproduction in any medium, provided the original author and source are credited. 
expression 'sustainable development' has been used in a variety of ways, depending on whether it is employed in an academic context, or that of planning, business or environmental policy context. As a result, during last 18 years we have been confronted with several different discourses of sustainable development, some of which are mutually exclusive” (Redclift, 2009, cited in: Papuziński, 2011).

Sustainable development is a subject of life and social sciences. Initially, in the 80 's, the concept of sustainable development was mainly identified with development that ensures durability and quality of natural resources in long term. In this approach, the assumption on lowing on natural resources under the influence of business achievement of relatively high dynamics of the GDP growth, has the key meaning, Therefore, present generation that is a disposer of natural resources, is obliged to preserve their durability for the next generations. In this approach, the notion of sustainable development is narrowed to its environmental aspects, attributing them a priority.

In the economic sciences, the definition of Pearce and Turner (1990) is the most known. According to them, sustainable development "involves maximising the net benefits of economic development, subject to maintaining the services and quality of natural resources over time." Economic development is meant not only as growth of income per capita, but also as improvement of other elements of social wealth. It also has to cover indispensable structural changes in economy and whole society.

In the further trials of specifying the sustainable development, the definition was enriched by new elements fitting in more comprehensive approach to development, which highlights simultaneously two aspects: sustainability and durability. A broader approach to durable and sustainable development dates back to the 90's of the XX century. It is recognised by treating this category as comprehensive development strategy of socio-economic development integrally covering entirety of world problems: natural environment degradation, differences in social wealth level, exclusion, threats for local and regional economy, globalisation, etc. Such approach does not bring the concept of the sustainable development to environmental aspects only, but it treats it broadly as forming of balanced proportions between mutually linked types of economic, human and natural capital, in order to ensure durable ground for improvement of life quality for current and future generations.

The initial condition for sustainable development concept realisation is recognising it as a new development paradigm, based on integrated order, i.e. economic, environmental and social order. It was also reflected in the approved by the European Council in 2001 "The EU Sustainable Development Strategy", and afterwards in the paper from 2010 „Europe 2020 - A strategy for smart, sustainable and inclusive growth”. In the current development strategy, the three priorities have been designated:

$1 \backslash$ smart growth, i.e. economy based on innovation and knowledge,

$2 \backslash$ sustainable growth promoting a more resource efficient, greening and more competitive economy,

$3 \backslash$ Inclusive growth fostering high employment level ensuring social and territorial cohesion.

It is worth mentioning that the General Assembly of the United Nations paid attention to two ideas: the first is related to the fact that the well-being of the environment, economies and people is inextricably linked and the second one highlights that sustainable development involves co-operation on a global scale. It means that sustainable development concept implementation inseparably connects with integration covering developing in the wide range of sectors, across borders and between generations (Strange, Bayley, 2008).

The implementation of sustainable development concept, from the very beginning encounters a number of difficulties, however in some fields of economic life, positive environmental effects fitting into its realisations have been noted. For example, between 1990 and 2004 the energy use grew by $30 \%$ and the $\mathrm{CO}_{2}$ emission by 26\%, while the GDP increased by over $50 \%$ (Sustainable..., 2007). Nevertheless, those changes are insufficient to compensate negative effects of the growth of scale and level of consumption generating high and increasing intake of natural resources. The data prove that influence of households behaviour on natural environment has escalated in the last three decades and in the next 20 years further growth is predicted, especially in relation to electricity consumption, use of means of transportation and waste production (Towards Sustainable..., 2002). Therefore, on the Earth Summit on Sustainable Development in September 2002 in Johannesburg, it was approved that one of the overriding aims of the future development is not sustainable production only, but also sustainable consumption. The other goals are reduction of poverty and management of resources fostering economic and social development. Realisation of those goals means, as Janoś-Kresło (2008) underlines, "change of consumption model, change of value system and such way of management, which causes that the pressure on environment does not exceed its capacity".

Since the World Summit, the sustainable consumption has been a subject of a number of debates, political and social. The fact that it is one of the aims included in many national and international strategies realised by 2020 proves the significance of the problem. In Poland, in 2003 the Strategy for Changes in Production and Consumption Patterns Fostering Realisation of Rules of Durable, Sustainable Development was adopted, in which it is stated that "the essential goal in consumption sphere should be such influence on society, which would allow to avoid unfavourable for the natural environment occurrence of 'overconsumption' and immediate transition to sustainable consumption".

\section{SUSTAINABLE CONSUMPTION AS A NEW CONSUMPTION PATTERN}

The concept of sustainable consumption is a response to the occurrence of consumptionism resulting in excessive use of natural resources (environmental aspect), waste (economic aspect) and social exclusion of particular social groups (social aspect). Side effects of consumptionism are weakening social cohesion and individualization of consumption. Consumptionism, or in other words consumerism, may be understood as a condition in which economic consumption 
becomes a way of life and in which more cultural functions are handed over to the act of consumption. Consequently, it is characterized by high level of material consumption and increasing environmental degradation (Evans, Jackson 2008)

Sustainable consumption is identified by part of the authors with pro-environmental consumption. In the Polish literature Jatrzębska-Smolaga (2002) presented such approach for the first time in a book devoted to this subject. In the case of consumption respecting environmental aspects, she used an adjective "durable". According to the author (2000), durable consumption is "identified with such consumption that does not create threats for natural environment and does not create stimuli for intensive exploiting of its resources. Durable consumption allows to continuously reproduce the subject of the consumption. Non-durable consumption, i.e. formerly developed, undermines further existence threatening to overload the natural environment". This definition is quoted by particular authors as the most giving the essence of the sustainable consumption (Żelazna-Blicharz, 2007). A number of researchers (Kramer, 2011, Cudowska-Sojko, 2012) rely on the definition adopted on the Norwegian symposium devoted to this subject (Norwegian..., 1994). According to Kramer (2011) sustainable consumption level occurs when "we consume material goods and services in a sufficient degree to satisfy basic needs and reach higher quality of life, minimizing use of natural resources, material harmful for environment originating on every stage of production, simultaneously not limiting rights of the next generations for such consumption". Therefore, it is such consumption level, which simultaneously allows to satisfy basic needs and achieve higher quality of life with the use of goods that minimize pressure on environment, preserving durability of resources for next generations. It comes to the consumption of goods and services, that to a minimal extent influences the use of natural resources, due to this it is simultaneously socially equitable, because it creates the possibility to use them by next generations. Similar approach, emphasizing the environmental aspect of sustainable consumption, is presented by a number of researchers (Dąbrowska and Ozimek, 2010; Kryk, 2013; Zrałek, 2012). Dąbrowska and Ozimek (2010) quote the International Institute for Environment and Development, that sustainable consumption is a demand management strategy aimed at using environmental resources and economic services in order to satisfy needs and raise the quality of everybody's life with simultaneous reconstruction of natural capital for the next generations. Similarly, the British National Consumer Council indicates that sustainable consumption is a balancing act that takes into account present consumers' quality of life alongside resource use and environmental impact so that the future consumers could have the same level of life quality as that is today (NCC, 2003). In turn, Zrałek (2012) quoting works of Moisander and Pesonen (2002) accepts that sustainable consumption is such, "which form and size determine a set of pro-environmental values and consumer attitudes leading to environmental awareness (or wider understood - social awareness) and environmentally (and socially) responsible process of market decision-making”. Kryk (2013) also pleads the above mentioned definition. Both quoted definitions result in the fact that the concept of sustainable consumption is considered by those authors in narrow meaning including its environmental aspects without other aspects, i.e. economic and social ones. In case of such narrowing down sustainable consumption concept, it is identified with its greening. However, it is difficult to accept the statement that the range of sustainable consumption manifestation limits itself to greening only. It is an important manifestation of sustainable consumption, but not one and only, because and the adjective "sustainable" indicates that we deal with new processes directed to balancing their three main aspects, i.e. economic, environmental and social ones.

Lorek and Fuchs (2011) also distinguish weak sustainable consumption and strong sustainable consumption. The weak sustainable consumption may be understood as focusing on improving the efficiency of consumption mainly through technological improvements that will spread through markets due to consumer demand. In turn, strong sustainable consumption bases on the assumption that changes in consumption level and patterns are necessary to achieve the sustainable consumption. Therefore, there is a need for reduction in resource consumption instead for product-based individual consumption. In this approach, sustainable consumption is not only an economic activity occurring on the market, but it considers people as citizens that accept social embeddedness of consumption decision.

Similarly, according to Kramer (2011) sustainable consumption integrates diverse social, economic and political practices on individuals, households and governmental level that aim at:

reduction of environmental effects of production, use and disposal of goods,

ensuring possibility to satisfy basic consumption needs for everybody,

increase of opportunities for sustainable development for the countries of the South,

consumption development of goods and services that have positive impact on health and welfare of women and children, development and application of energy saving devices,

development of public transportation and pro-environmental development of green goods and services adjusted to the global requirements of the environment,

- promotion of lifestyles emphasizing social cohesion, local traditions, and immaterial values.

The approach to the sustainable consumption presented by Kramer, indeed strongly highlights its environmental aspects, however it refers to the social issues such as sustainable development of the countries of the South, social cohesion and local tradition. The wide view on sustainable consumption is presented by Kiełczewski (2004), who analyses it in economic, environmental, social, psychological, spatial and time aspect (Table 1).

Thus, in wide approach, sustainable consumption involves a number of diverse components and not all of them are measurable and therefore cannot be included into the cost and benefits calculations (Jastrzębska-Smolaga, 2000). Similarly as sustainable development, the sustainable consumption is formed by at least three dimensions: economic, environmental and social. At the present stage of empirical studies, environmental aspect is strongly emphasized in relation to a significant imbalance in this field. In the environmental dimension, originating from it, sustainable consumption manifests itself in:

greening of goods and services consumption, 
deconsumption, i.e. quantitative limitation of goods consumption,

collaborative consumption,

responsible consumption.

Table 1. The multifaceted sustainable consumption

\begin{tabular}{|l|l|}
\hline Type of aspect & Essence \\
\hline economic & $\begin{array}{l}\text { the efficient proportion between present and future consumption is set, and what follows that do not cause } \\
\text { significant disorder of economic balance }\end{array}$ \\
\hline environmental & $\begin{array}{l}\text { the consumption utility is maximized with simultaneous maintenance of utility and quality of natural } \\
\text { resources and natural environment, enabling direct consumption of natural goods, preference of such } \\
\text { consumption forms, which are the least burdensome for the environment }\end{array}$ \\
\hline social & $\begin{array}{l}\text { the consumption is relatively evenly distributed, which means that is available for all people, } \\
\text { independently from time and space, at least in the area of required goods, preference of such consumption } \\
\text { forms, which cause social problems in the lowest degree }\end{array}$ \\
\hline psychological & $\begin{array}{l}\text { consumption processes cause growth of quality of life, that is establishing optimal balance between } \\
\text { material consumption and satisfying material needs }\end{array}$ \\
\hline demographic & $\begin{array}{l}\text { demographic conditions do not constitute a permanent obstacle of consumption growth; the life } \\
\text { expectancy increases, health condition improves and affiliation to demographic or socio-professional } \\
\text { group is not a factor limiting the accessibility to socially required goods }\end{array}$ \\
\hline spatial & the means of needs satisfaction do not violate spatial order \\
\hline time & the above dimensions of sustainable consumption are possible to realize in unlimited time \\
\hline Source: Kiekzewski D. 2008. Konsumpcja a perspektywy trwałego i zrównoważonego rozwoju, Białystok, p. 57-58.
\end{tabular}

Source: Kiełczewski D. 2008. Konsumpcja a perspektywy trwałego i zrównoważonego rozwoju, Białystok, p. 57-58.

All mentioned manifestations of sustainable consumption are an alternative stream in relation to the consumerism of common character. Considering strongly awoken needs of the present society and increasing production possibilities of their satisfaction, it is very difficult to expect that in the nearest future sustainable consumption could replace this occurrence. Therefore, it may have only complimentary character and not a substitutive one. As Kiełczewski (2012) rightly points out „The basic feature of the consumption process, more and more strongly observed in the recent years, has been its growing diversification. It not only means that a unified pattern of mass consumption has been gradually becoming less and less current, but also probably one will not be able to consider one detailed life model called sustainable consumption".

\section{THE CONDITIONS OF SUSTAINABLE CONSUMPTION CONCEPT REALISATION AND THEIR LIMITATIONS}

The changes in consumption towards its balancing do not occur automatically, but in the process of their creation, they require participation of a number of organisations functioning in the economy and its surroundings. As JastrzębskaSmolaga (2000) claims „In the concept of durable consumption the direction and aim of its development has been outlined. In turn, there were not created any new tools (not only economic) for realisation of this aim (...). The economic tools elaborated for registration of quantitative changes in non-durable consumption model are for now adopted "for measurement" of durable consumption". Therefore, for present stage of sustainable consumption concept implementation, only some noticeable minimal tools are applied and their effectiveness may be observed in longer term.

Achieving sustainable consumption in practice requires defined transformations both on supply and demand side (Adamczyk, 2012). The first ones depend on lower use of natural resources in result of improvement of green goods and services production efficiency and due to that, lower pressure of consumption process on the environment. In turn, the second ones boil down to changes of consumption patterns depending mainly on its environmental rationality understood as such selection of the consumed goods and services that minimizes the environmental burden in their entire life cycle. From the variety of supply conditions, the following have the key meaning in transition to sustainable consumption: - availability (physical and price) of consumer goods with lower pressure on the environment in the entire life cycle,

- the offer of green product innovation (so-called eco-innovation), development of eco-labelling system covering basic group of consumer goods (food, household appliances, cleaning agents),

- availability of particular green infrastructure (cycle paths, public transportation).

A number of obstacles, mainly of price-cost character, limit fulfilling the supply conditions. However, those changes are an insufficient condition, in order to reorient the existing consumption pattern towards its balancing, because it requires fundamental transformations in value system and social awareness. Among particular consumer groups, the conviction concerning the need for this kind of changes ("a green consumer") is growing; nevertheless, it is a very difficult process, slowed down by many obstacles. First, sustainable consumption requires a transition from egoistic attitude oriented towards needs satisfaction to the attitude of environmental awareness, which primarily requires reorientation of value system. According to Rok (2002), it demands conversion of thinking from "I" to "we", from more to "enough", from "materialism" to a "holistic approach", from "short-term" to "long-term" thinking. Second, change in consumer habits and wonts basing on reoriented value system is possible in long- and not in short-term. Third, households influence the environment in dispersed way using diverse goods and services, therefore the condition for reaching positive results is a significant scale of changes in consumer behaviours covering possibly large group of products. 


\section{Proceedings of the $8^{\text {th }}$ International Scientific Conference Rural Development 2017}

Practical realisation of sustainable consumption concept is conditioned not only by consumers and producers activity in this area, but also by the state and non-governmental organisations. Particular meaning is attributed to the government, because it has wide possibilities to form changes towards sustainable consumption using the following tools: - informational (campaigns raising environmental awareness of society, education directed towards improvement of information on products and environmental effects of their use),

- economic and financial (stimulating particular adjustment processes on production side, restructuring of resourceconsuming sectors, promoting environmental-friendly technologies),

- legal (changes in environmental protection law).

The authorities mainly focus on the policy strategy basing on informational instruments. It seems that in spite of some improvement, applying these tools is insufficient, in order to significantly change consumer behaviours dominated by willingness to possess increasing quantity of goods. Therefore, currently sustainable consumption occurs on the margin of mainstream of those processes. However, according to Lorek and Fuchs (2011) the situation may improve, if more effective hard policies, like regulatory and economics instruments are applied on larger scale. Stronger engagement of government and civil societies and their organizations as well as strengthening social innovation and clear, convincing information on benefits of sustainable societies may contribute to the sustainable consumption increase (Lorek, Spangenberg 2014).

\section{CONCLUSIONS}

Interdisciplinary character of sustainable consumption concept, similarly as sustainable development causes that it is defined in a number of different ways. At the present stage of studies, the environmental dimension is mostly highlighted. Therefore, sustainable consumption is generally identified with green consumption. Nevertheless, in the recent years the attention has been paid to its new diverse manifestations in form of collaborative consumption, deconsumption or responsible consumption, which are alternatives to the common consumptionism. Meanwhile, attributing to products and services of sustainable character particular features and signs may turn out an opportunity for sustainable consumption increase. Consumption of those goods constitutes consuming of some meanings rather than specific goods.

Attaining sustainable consumption involves changes on the supply side (lower resources consumption resulting from ecological efficiency improvement of production) and demand side (amount of the consumed goods). However, implementation of those changes is relatively cost-consuming and requires modifications in attitudes and behaviours of consumers. Practical realisation of sustainable consumption concept includes application of particular tools (informational, economic and regulatory) on governmental level, wherein two last one seem to be more effective.

Nevertheless, in spite of the considerations conducted in the paper, a weak recognition of this issue indicates a need for development of research in this area, particularly concerning sustainable consumption manifestations and factors determining their existence both on demand and supply side.

\section{REFERENCES}

1. Adamczyk, W. 2012. Współczesne problemy zrównoważonej produkcji i zrównoważonej konsumpcji. Zarządzanie i Finanse, Vol. 10, Iss. 3, pp. 179-180. [In Polish]

2. Bywalec, Cz. 2010. Konsumpcja a rozwój gospodarczy i społeczny. Wyd. C.H. Beck, Warszawa, pp. 195-196. [In Polish]

3. Cudowska-Sojko, A. 2012. Zrównoważony rozwój a globalizacja konsumpcji. Handel Wewnętrzny, Vol. I, pp. 20. [In Polish]

4. Dąbrowska, A., Ozimek I. 2010. Zrównoważona konsumpcja i produkcja jako atrybut wspótczesnych społeczeństw $i$ gospodarek. [in:] Ekoinnowacyjność dziś i jutro - wyzwania, bariery rozwoju oraz instrumenty wsparcia, ed. L. Woźniak, J. Strojny, E. Wojnicka, PARP, Warszawa, p. 46. [In Polish]

5. Europe 2020 - A strategy for smart, sustainable and inclusive growth. European Commision, 3.3.2010, Com(2010), 2010. Brussels.

6. Evans, D., Jackson, T. 2008. Sustainable consumption: Perspectives from Social and Cultural Theory. RESOLVE Working Paper 05-08. Research Group on Lifestyles, Values and the Environment Centre for Environmental Strategy, University of Surrey, Guildford, p. 7.

7. Janoś-Kresło, M. 2008. Ustugi społeczne a zrównoważony rozwój regionów. Mono. i Opraco., 554, Szkoła Główna Handlowa, Warszawa, p. 45. [In Polish]

8. Jastrzębska-Smolaga, H. 2000. W kierunku trwałej konsumpcji. Dylematy zagrożenia szanse, Wyd. Naukowe PWN, Warszawa, pp. 73-75. [In Polish]

9. Kiełczewski, D. 2004. Konsumpcja a perspektywy trwałego i zrównoważonego rozwoju. Wyd. Uniwersytetu w Białymstoku, Białystok, pp. 57-58.

10. Kiełczewski, D. 2012. Różnorodność stylów życia jako czynnik rozwoju zrównoważonego. Ekonomia i Środowisko 3(43), p. 78.

11. Kryk B. 2013. Zrównoważona jakość życia a zrównoważona konsumpcja i zachowania ekologiczne polskich konsumentów. Handel Wewnętrzny, Vol. 6, pp. 7-8. [In Polish]

12. Kramer, J. 2011. Konsumpcja - ewolucja ról i znaczeń. Konsumpcja i rozwój, Vol. 1, p. 8. [In Polish]

13. Lorek, S., Fuchs, D. 2011. Strong sustainable consumption governance - precondition for a degrowth path? Journal of Cleaner Production, Vol. 38, pp. 36-43. https://doi.org/10.1016/j.jclepro.2011.08.008

14. Lorek, S., Spangenberg, J.H., 2014. Sustainable consumption within a sustainable economy - beyond green growth and green economies. Journal of Cleaner Production, Vol. 63, pp. 33-44. https://doi.org/10.1016/j.jclepro.2013.08.045 
15. Moisander J. 2007. Motivational complexity of green consumerism. International Journal of Consumer Studies, Vol. 31, Issue 4, p.404-409. https://doi.org/10.1111/j.1470-6431.2007.00586.x

16. Moisander J., Pesonen S. 2002. Narratives of sustainable ways of living: Constructing the self and others as a green consumer, Management decision, Vol. 40(4), p. 336. https://doi.org/10.1108/00251740210426321

17. National Consumer Council 2003. Green Choice, What choice? London.

18. Norwegian Ministry of the Environment 1990 .Oslo Roundtable on Sustainable Production and Consumption.

19. Papuziński, A. 2011. Realizacja zrównoważonego rozwoju. Problemy Ekorozwoju, Vol. 6 (1), p. 108.

20. Pearce, D., Turne,r R. K. 1990. Economics of Natural Resources and the Environment. Harvester Wheatsheaf, New York, p. 11.

21. Rok, B. 2002. Etapy rozwoju wspótczesnego konsumeryzmu a kształtowanie wzorców konsumpcji. [in:] Rola organizacji pozarządowych w kształtowaniu proekologicznych wzorców konsumpcji, Instytut na Rzecz Ekorozwoju, Warszawa, p. 45.

22. Strange, T., Bayley, A. 2008. Sustainable development. Linking Environment. Society, Economy, OECD.

23. Sustainable Consumption and Production. Promoting Climate-Friendly Household Consumption Patterns, United Nations Department of Economic and Social Affairs. 30 April 2007, p. 4. Available at www.greeningtheblue.org/sites/default/files/Sustainable\%20consumption\%20\&\%20Production.pdf (Accessed on 30/12/2014).

24. Towards Sustainable Household Consumption? Trends and Policies in OECD Countries. OECD 2002, p. 2. Available at http://www.oecd.org/greengrowth/consumption-innovation/1938984.pdf (Accessed on 28/12/2014)

25. Zrałek, J. 2012. Dekonsumpcja jako przejaw proekologicznych zachowań konsumentów. Handel Wewnętrzny, Vol. II, pp. 135136. [In Polish]

26. Żelazna-Blicharz A. 2007. Spoteczna odpowiedzialność w procesie gospodarowania a zrównoważona produkcja i konsumpcja. Politechnika Lubelska, Lublin, p. 55. [In Polish] 